\title{
Pengaruh Dukungan Suami Terhadap Pemilihan Metode Alat Kontrasepsi Intra Uterine Device (IUD)
}

\author{
The Effect Of Husband Support On Selection Of Contraception \\ Intra Uterine Device Methods (IUD)
}

\author{
Endah Mulyani $^{1}$, Aidha Rachmawati ${ }^{2}$, Rizka Esty Safriana ${ }^{3}$ \\ ${ }^{1,2,3}$ Fakultas Kesehatan Prodi D IV Kebidanan Universitas Muhammadiyah Gresik \\ Email : aidha.rachmawati@umg.ac.id
}

\begin{abstract}
ABSTRAK
Alat kontrasepsi IUD merupakan metode yang dapat bertahan 5-10 tahun serta memiliki tingkat keefektifitasan yang tinggi namun pemilihan metode IUD di Indonesia masih rendah yaitu hanya sebesar 7,07\% pada tahun 2017 dan hanya sebesar 7,6\% untuk kabupaten Sidoarjo. Penelitian ini bertujuan untuk melihat pengaruh dukungan suami terhadap pemilihan metode alat kontrasepsi IUD.

Penelitian ini merupakan penelitian analitik dengan pendekatan cross sectional. Populasi dalam penelitian adalah peserta KB aktif di Desa Sidomulyo pada bulan Juli yaitu sebesar 860 orang, besar sampel yang digunakan adalah 273 yang diambil dengan menggunakan metode probability sampling dengan teknik proporsional random sampling. Variabel independen dalam penelitian ini adalah dukungan suami sementara variable dependen adalah pemilihan metode IUD. Data yang terkumpul akan diolah dengan menggunakkan uji regresi logistik.

Hasil penelitian menunjukkan bahwa hampir seluruh wus yang tidak mendapat dukungan dari suami tidak memilih IUD sebagai alat kontrasep dan berdasarkan uji statistic dukungan suami memiliki pengaruh terhadap pemilihan metode kontrasepsi yaitu sebesar 0,000 dengan nilai OR 61,18.

Berdasarkan hasil penelitian diatas dapat disimpulkan untuk meningkatkan pemilihan metode IUD maka perlu untuk dilakukan pengenalan atau sosialiasi mengenai IUD terhadap suami wus.
\end{abstract}

Kata Kunci : Dukungan suami, IUD, alat kontrasepsi

\begin{abstract}
IUD contraception is a method that can last 5-10 years and has a high level of effectiveness but the selection of IUD methods in Indonesia is still low at only $7.07 \%$ in 2017 and only 7.6\% for Sidoarjo district. This study aims to look at the effect of husband support on the selection of IUD contraceptive methods.

This research is an analytic study with cross sectional approach. The population in the study were active family planning participants in Sidomulyo Village in July, amounting to 860 people, the sample size was 273 taken using probability sampling method with proportional random sampling technique. The independent variable in this study is husband support while the dependent
\end{abstract}


variable is the selection of the IUD method. The collected data will be processed by using a logistic regression test.

The results showed that almost all women who did not have support from their husbands did not choose an IUD as a contraceptive device and based on statistical tests husband's support had an influence on the selection of contraceptive methods, which was 0,000 with an OR of 61.18.

Based on the results of the research above, it can be concluded to improve the selection of the IUD method, it is necessary to introduce or socialize the IUD to the husband.

Keywords: Husband support, IUD, contraception.

\section{PENDAHULUAN}

Penduduk adalah salah satu faktor yang berperan penting dalam tingkat kesejahteraan suatu negara, karena jumlah penduduk yang tinggi akan menimbulkan masalah sehingga pertumbuhan penduduk perlu mendapat perhatian yang lebih dari pemerintah. Indonesia dari tahun 2012 sampai 2014 terus mengalami peningkatan jumlah penduduk bahkan Badan Koordinasi Keluarga Berencana Nasional (BKKBN) memperkirakan laju pertumbuhan penduduk akan mencapai 450 juta jiwa pada tahun 2045 .

Pemerintah mencanangkan program keluarga berencana menjadi program pembangunan sosial dasar yang penting bagi kemajuan bangsa. Program KB merupakan program yang bertujuan untuk mencegah terjadinya ledakan penduduk yang nantinya dapat membawa dampak negatif bagi negara. Program KB adalah upaya untuk mengatur kelahiran anak, jarak dan usia ideal melahirkan, mengatur kehamilan melalui promosi, perlindungan dan bantuan sesuai dengan hak reproduksi.

Program keluarga berencana berperan untuk menurunkan angka kesakitan dan kematian ibu dan bayi karena kehamilan yang terencana dan diinginkan akan menurunkan resiko kematian akibat usia ibu yang belum matang, jarak terlalu dekat atau jumlah kelahiran yang terlalu dekat. Pelayanan KB diharapkan dapat menurunkan tingkat percepatan pertumbuhan penduduk tidak melebihi kemampuan negara, sehingga diharapkan taraf kehidupan rakyat diharapkan meningkat.

Alat kontrasepsi adalah alat yang digunakan untuk menghindari atau mencegah terjadinya kehamilan sebagai akibat adanya pertemuan antara sel telur dan sel sperma. Alat kontrasepsi banyak jenisnya salah satu alat kontrasepsi yang efektifitasnya tinggi adalah Intra Uterine Device (IUD). Alat kontrasepsi IUD adalah salah satu metode kontrasepsi yang dilakukan dengan memasukkan alat khusus yang terbuat dari bahan plastik, disertai barium sulfat, logam, tembaga dan progestoron kedalam rahim. Kontrasepsi jenis IUD adalah metode kontrasepsi yang berjangka panjang dan dapat dipakai hingga 5 10 tahun dan efektif menurunkan angka kehamilan dengan 0,6 - 0,8 kehamilan/100 perempuan. 
Berdasarkan hasil laporan Kementerian Kesehatan Republik Indonesia penggunaan Intra Uterine Device (IUD) di Indonesia setiap tahunnya mengalami penurunan. Pada tahun 2016 sebesar 10,61\% menjadi 7,15\% pada tahun 2017. Penurunan ini juga terjadi di Provinsi Jawa Timur yang pada tahun 2016 sebesar $12,65 \%$ menjadi 7,07\% pada tahun 2017. Kabupaten Sidoarjo pengguna metode IUD sangat rendah yaitu 7,6\% pada tahun 2017. Rendahnya penggunaan metode IUD berbanding terbalik dengan penggunaan metode suntik yang terus mengalami peningkatan setiap tahunnya.

Berdasarkan profil kesehatan Kabupaten Sidoarjo di wilayah kerja puskesmas krian jumlah peserta KB baru yang memilih metode IUD pada tahun 2017 hanya mencapai 4,5\% angka ini sangat rendah bila dibandingkan dengan wilayah puskesmas sekardangan yang mencapai $10.5 \%$. Melihat uraiaun diatas dapat kita lihat bahwa dari tingkat nasional hingga lokal pemilihan metode KB IUD terus mengalami penurunan. Menurunnya pemilihan KB IUD disebabkan oleh beberapa faktor antara lain kurang pengetahuan dan pemahaman tentang AKDR namun juga karena rendahnya dukungan suami.

Suami adalah salah satu orang yang paling penting dalam kehidupan seorang istri dan peran suami dalam pemilihan alat kontrasepsi sangat penting karena suami merupakan motivator, educator dan fasilitator dalam pemilihan alat KB. Pemilihan kontrasepsi dan kepuasaan dalam penggunaanya sangat dipengaruhi oleh suami, dukungan yang diberikan akan memantapkan pemakaian alat kontrasepsi istri.

Dukungan suami dalam pemlihan alat kontrasepsi meliputi upaya memperoleh informasi, memilih, mengantar ke tempat pelayanan serta membiayai pemasangan alat kontrasepsi. Melihat besarnya peran dukungan suami terhadap pemilihan metode kontrasepsi maka peneliti ingin melihat lebih lanjut mengenai pengaruh dukungan suami terhadap pemlihan metode IUD.

\section{METODE}

Penelitian ini merupakan jenis penelitian analitik dengan metode pendekatan cross sectional dengan populasi sebesar 860 peserta KB aktif dengan sampel sebesar 273. Pengambilan sampel dengan menggunakkan metode probability sampling dengan teknik proporsional random sampling. Variabel independen dalam penelitian ini adalah dukungan suami sementara variable dependen adalah pemilihan metode IUD. Data yang terkumpul akan diolah dengan menggunakkan uji regresi logistic dengan nilai $\mathrm{p}<$ 0,005 . 


\section{HASIL PENELITIAN}

1. Data Umum

Tabel 1. Data umum peserta KB aktif di Ds.Sidomulyo Kec. Krian Kab. Sidoarjo.

\begin{tabular}{|c|c|c|}
\hline Karakteristik & $\mathbf{n}$ & $\%$ \\
\hline \multicolumn{3}{|l|}{ Umur peserta $\mathrm{KB}$ aktif } \\
\hline$\leq 30$ tahun & 38 & 13,9 \\
\hline$>30$ tahun & 235 & 86,1 \\
\hline \multicolumn{3}{|l|}{ Paritas peserta KB aktif } \\
\hline 1 anak & 59 & 21,6 \\
\hline$>1$ anak & 214 & 78,4 \\
\hline \multicolumn{3}{|l|}{ Pendidikan peserta KB aktif } \\
\hline Dasar & 81 & 29,7 \\
\hline \multicolumn{3}{|l|}{ Lanjutan } \\
\hline \multicolumn{3}{|l|}{ Pendidikan suami } \\
\hline Dasar & 62 & 22,7 \\
\hline Lanjutan & 211 & 77,3 \\
\hline Total & 273 & 100 \\
\hline
\end{tabular}

2. Pengaruh dukungan suami terhadap pemilihan metode IUD

Tabel 2. Pengaruh dukungan suami terhadap pemiliham metode IUD di Ds. Sidomulyo Kec. Krian Kab.Sidoarjo.

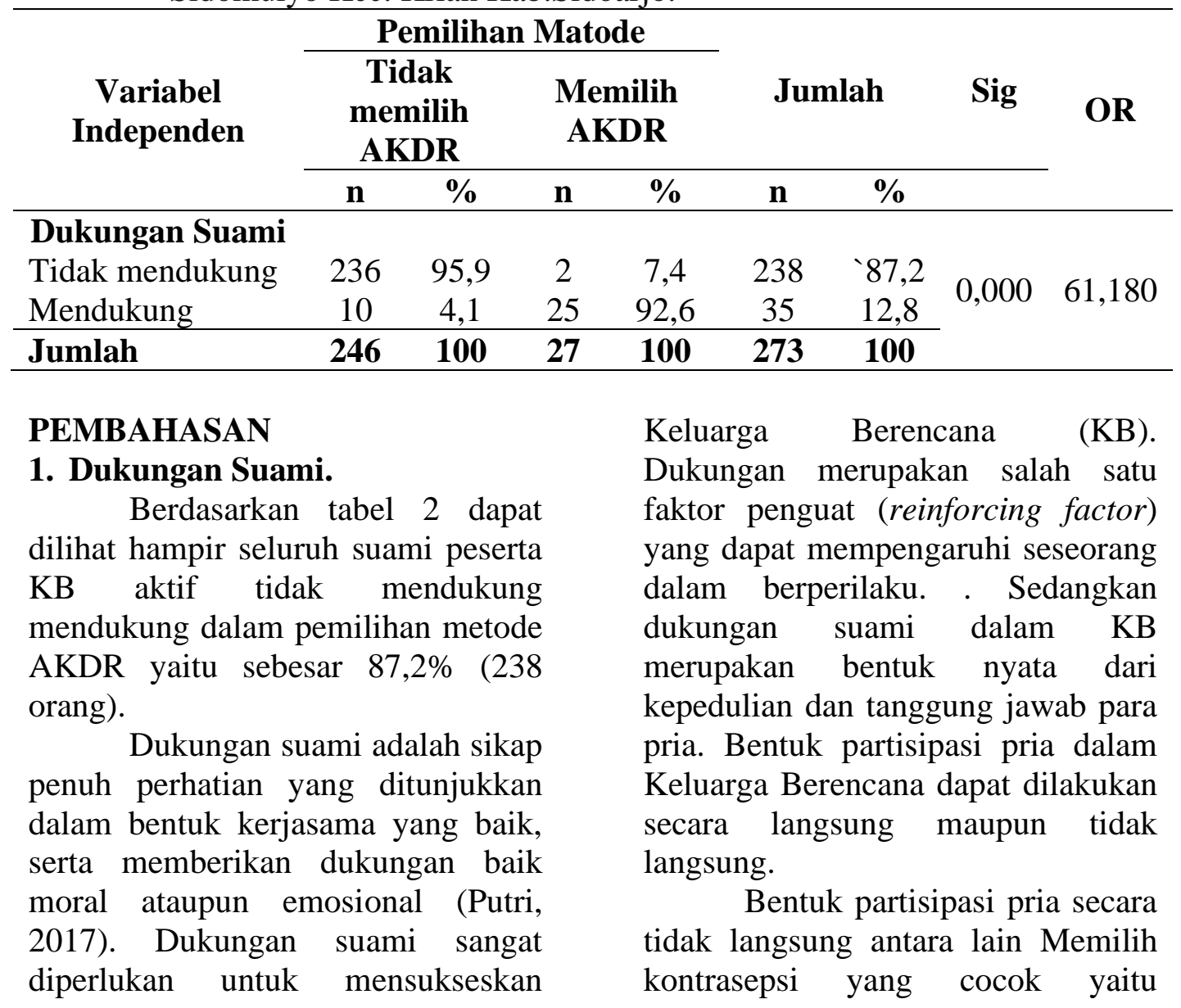


kontrasepsi yang sesuai dengan keinginan dan kondisi istrinya, Membantu istrinya dalam menggunakan kontrasepsi secara benar, seperti mengingatkan saat minum pil $\mathrm{KB}$, dan mengingatkan istri untuk kontrol, Membantu mencari pertolongan bila terjadi efek samping maupun komplikasi dari pemakaian alat kontrasepsi, Mengantarkan istri ke fasilitas pelayanan kesehatan untuk kontrol atau rujukan, Mencari alternatif lain bila kontrasepsi yang digunakan tidak cocok, Menggantikan pemakaian kontrasepsi bila keadaan kesehatan istri tidak memungkinkan.

$\begin{array}{lcr}\text { Dukungan } & \text { suami yang } \\ \text { rendah atau } & \text { negatif akan } \\ \text { mempengaruhi } & \text { pengambilan }\end{array}$ keputusan seorang istri dalam memilih kontrasepsi. Dukungan suami meliputi upaya memperoleh informasi, mengantarkan ke pelayanan kesehatan, dan membiayai pemasangan alat kontrasepsi. Semakin baik dukungan yang diberikan oleh suami maka dalam pengambilan keputusan sesuai dengan keinginan suami dan istri.

\section{Pemilihan Metode IUD.}

Berdasarkan tabel 2 dapat dilihat hamper srluruh peserta KB aktif tidak memilih metode kontrasepsi IUD yaitu sebsar 90,10\% (246 orang).

Tujuan utama pelaksanaan KB adalah meningkatkan derajat kesehatan dan kesejahteraan ibu dan anak, keluarga serta masyarakat pada umunya.keberhasilan pelaksanaan KB diharapkan angka kelahiran dapat diturunkan, sehingga tingkat kecepatan perkembangan penduduk tidak melebihi kemampuan kenaikan produksi, maka dengan demikian taraf kehidupan dan kesejahteraan rakyat diharapkan akan lebih meningkat.

Salah satu strategi dari pelaksanaan program KB sendiri seperti tercantum dalam Rencana Pembangunan Jangka Menengah (RPJM) tahun 2015-2019 adalah meningkatnya penggunaan metode kontrasepsi jangka panjang (MKJP). Berdasarkan lama efektifitasnya kontrasepsi dibagi menjadi dua metode yaitu MKJP (Metode Kontrasepsi Jangka Panjang) dengan jenis Implan/susuk, IUD (Intra Uterine Device), MOP (metode operasi pria), MOW (metode operasi wanita). Sedangkan Non MKJP dengan jenis kondom, pil, suntik, dan metode lain yang tidak termasuk dalam MKJP. Program kontrasepsi yang digalakan adalah metode kontrasepsi jangka panjang (MKJP) dengan implan dan IUD adalah salah satu metode unggulannya.

Berdasarkan penelitian yang dilakukan oleh Supiani (2015), mengatakan bahwa MKJP IUD/AKDR dinilai merupakan metode kontrasepsi yang paling efektif dari pada kontrasepsi jenis lain.. Keputusan Peserta KB aktif dalam memilih metode AKDR selain dilihat dari karakteristik umur, pendidikan dan pekerjaan juga ada banyak faktor lain yang mempengaruhi. Seringkali ibu merasa malu karena dalam pemasangan AKDR terjadi kontak secara langsung dengan alat reproduksi. Pemahaman masyarakat yang keliru tentang biaya metode AKDR dianggap lebih mahal, padahal jika dipahami bahwa biaya tersebut hanya dikeluarkan sekali dalam kurun waktu 3-5 tahun. 


\section{Pengaruh Dukungan Suami terhadap Pemilihan Metode IUD.}

Berdasakan tabel 2 dapat dilihat hampir seluruh peserta KB aktif yang tidak mendapat dukungan suami tidak memilih IUD sebagai alat kontrasepsi mereka yaitu sebesar 95,9\% (236 orang) dan berdasarkan hasil uji regresi logistic dukungan suami berpengaruh terhadap pemilihan metode IUD sebesar $\mathrm{p}=$ 0,000 dan OR sebsar 61,80.

Hasil penelitian ini juga sesuai dengan penelitian Aryanti (2014) dan Nurbaiti (2013) yang mengatakan bahwa terdapat pengaruh dukungan suami dengan penggunaan alat kontrasepsi. Peran suami sangat dibutuhkan sebagai motivator dengan memberikan motivasi atau dorongan terhadap istri, apalagi dalam memilih memanfaatkan pelayanan KB AKDR.

Nuryati \& Fitria (2014), juga mengungkapkan ada hubungan yang bermakna antara dukungan suami dengan pemilihan alat kontrasepsi. Sehingga, dapat disimpulkan bahwa semakin tinggi dukungan dari suami. maka semakin tinggi pula prosentase penggunaan alat kontrasepsi yang sesuai dengan karakteristik dan kebutuhan istri.

Suami merupakan pemimpin dan pelindung istri, maka kewajiban suami terhadap istrinya adalah mendidik dan mengarahkan istrinya kepada kebenaran, kemudian memberinya nafkah lahir batin, mempergauli serta menyantuni dengan baik. Apabila pasangan tidak saling berkomunikasi untuk mendiskusikan kebijakan dalam merencanakan keluarga berencana, yang terjadi adalah timbulnya hambatan terhadap kelangsungan pemakaian alat kontrasepsi. Peran tenaga medis untuk lebih efektif dalam hal dukungan suami yaitu dibentuknya kelas ayah, harapannya yaitu membantu dalam hal menambah pengetahuan suami, sehingga bisa mengayomi istri dalam pengambilan keputusan.

Menurut asumsi peneliti dengan melihat hasil pengelolahan data tersebut menunjukkan bahwa responden tidak mendapatkan dukungan suami dalam pemilihan metode kontrasepsi sehingga kebanyakan responden memilih metode kontrasepsi sederhana. Dukungan dari suami dalam penggunaan kontrasepsi sangat diperlukan karena tanpa adanya dukungan dari suami rasa nyaman untuk menggunakan kontrasepsi tidak akan didapatkan, dalam memilih metode kontrasepsi pasangan suami isteri membicarakan atau mempertimbangkan secara bersama-sama untuk memilih metode kontrasepsi terbaik yang disetujui bersama, saling bekerja sama dalam penggunaan kontrasepsi, memperhatikan tanda-tanda bahaya penggunaan kontrasepsi dan menanggung biaya untuk penggunaan kontrasepsi.

\section{SIMPULAN}

Suami peserta KB aktif di Ds. Sidomulyo Kec.krian Kab.Sidoarjo bulan Juli 2019 yang tidak mendukung dalam pemilihan netode IUD yaitu sebanyak 238 orang (87,2\%).

Peserta KB aktif di Ds. Sidomulyo Kec.Krian Kab.Sidoarjo pada bulan Juli 2019 hampir seluruhtnya tidak memilih menggunakkan metode IUD yaitu sebanyak 246 orang $(90,10 \%)$. 


\section{SARAN}

Bagi peneliti selanjutnya dapat dijadikan bahan acuan dalam melakukan penelitian yang berkaitan dengan hubungan dukungan suami dengan pemilihan alat kontrasepsi dan penyebab rendahnya minat memilihi AKDR sebagai alat kontrasepsi.

Tenaga kesehatan diharapkan lebih meningkatkan penyuluhan dan pendidikan kesehatan mengenai AKDR pada WUS dan suami di daerah tersebut

\section{DAFTAR PUSTAKA}

Ainun, Nur. Dukungan Suami terhadap Pemilihan $K B$ Implan di Wilayah Kerja Puskesmas Paku Alam Kota Yogyakarta. Karya Tulis Ilmiah Program Studi DIII Kebidanan. STIKES Jendral Achmad Yani: Yogyakarta

Arikunto, S. 2010. Prosedur Penelitin. Rineka Cipta. Jakarta

BKKBN. 2008. Peningkatan Akses dan Kualitas Pelayanan KB. Bandung : BKKBN

BKKBN. 2005. Kebijakan Program Pokok dan Kegiatan Bidang Pelayanan Keluarga Berencana dan Kesehatan Reproduksi 2005-2009. Jakarta: BKKBN

BKKBN. 2007. Gender dalam Keluarga Berencana dan Kesehatan Reproduksi. Jakarta. BKKBN

Dinas Kesehatan Provinsi Jawa Timur. 2012. Profil Kesehatan Provinsi Jawa
Timur. Dinas Kesehatan Provinsi Jawa Timur. Surabaya

Dinas Kesehatan Provinsi Jawa Timur. 2015. Profil Kesehatan Provinsi Jawa Timur. Dinas Kesehatan Provinsi Jawa Timur. Surabaya

Everett, Suzanne. 2010. Buku Ajar Kesehatan Reproduksi Wanita Edisi 2. EGC: Jakarta

Fatimah, Dewi, 2013. Faktor Faktor Yang Berhubungan Dengan Penggunaan Alat Kontrasepsi Dalam Rahim (AKDR) Di Wilayah Kerja Puskesmas Kecamatan Pasar Rebo Jakarta Timur. Skripsi Ilmu Keperawatan. Fakultas Kedokteran dan Ilmu Kesehatan UIN Syarif Hidayatullah: Jakarta

Friedman. 2010. Buku Ajar Keperawatan Keluarga : Riset, Teori dan Praktik Edisi 5. EGC. Jakarta

Hartanto, H. 2004. Ragam Metode Kontrasepsi. Jakarta: EGC

Hartanto, H. 2010. Keluarga Berencana dan Kontrasepsi. Jakarta: EGC

Kementrian Kesehatan Republik Indonesia. 2016. Profil Kesehatan Indonesia 2016. Kementerian Kesehatan Republik Indonesia. Jakarta

Khoirunnisa, Lutfia. 2014. Hubungan Dukungan Suami dengan Pemilihan 
Kontrasepsi IUD Pada Akseptor Kontrasepsi IUD Di Puskesmas Tegalrejo Tahun 2014. Skripsi Program Studi DIV Bidan Pendidik. Stikes Aisyiyah Yogyakarta

Liando, Frisca, Meiske Runkar dan Iyan Manueke. Faktor faktor yang Berhubungan Dengan Penggunaan Alat Kontrasepsi Dalam Rahim (AKDR) Di Kelurahan Pangolombian Kota Tomohon Tahun 2013. Jurnal Ilmiah Bidan Vol 1 No 1 : 46 $-50$

Nursalam. 2009. Psikologi Keluarga. Salemba Medika : Jakarta

Notoatmodjo, S., 2005. Metodologi Penelitian Kesehatan. Jakarta: Rineka Cipta.

2007. Promosi Kesehatan dan Ilmu Perilaku, Jakarta: Rineka Cipta Pinem, Saroha. 2009. Kesehatan Reproduksi dan Kontrasepsi.Trans Info Media: Jakarta

Putri, Chieng. 2017. Gambaran Dukungan Suami Terhadap Akseptor KB IUD dan Implan di Wilayah Kerja Puskesmas Gamping I Sleman Yogyakarta. Karya Tulis Ilmiah Program Studi DIII Kebidanan. STIKES Jendral Ahmad Yani Yogyakarta

Prawirohardjo, S. 2008. Ilmu Kebidanan. Bina Pustaka : Jakarta
Proverawati. 2010. Panduan memilih kontrasepsi. Jakarta : Nuha Medika

Republik Indonesia. 2009. Undang Undang Nomor 36 Tahun 2009 tentang Kesehatan. Lembaran Negara Republik Indonesia Tahun 2009, Nomor $144 \quad$ Sekertaris Negara. Jakarta

Riyanto, A. 2009. Pengolahan dan Analisis Data Kesehatan (Dilengkapi Uji Validitas dan Reliabilitas serta Aplikasi Program SPSS). Yogjakarta: Nuha Medika.

Suratun. 2008. Pelayanan Keluarga Berencana dan Pelayanan Kontrasepsi. Trans Info Media : Jakarta

Sulistiyowati, A. 2011. Faktor faktor yang Mempengaruhi Pemilihan Kontrasepsi Implant Pada Pasangan Usia Subur : Pelayanan Keluarga Berencana. Salemba Medika: Jakarta

Saifuddin, Abdul Bari. 2006. Buku Panduan Pelayanan Kontrasepsi Edisi 2. Yayasan Bina Sarwono Prawirohardjo: Jakarta

Wiknojosastro, H. 2006. Ilmu Kebidanan. Jakarta: Yasan Bina Pustaka Sarwono Prawiroharjo 